\title{
Effect of supplementation of beef cattle with different protein levels and degradation rates during transition from the dry to rainy season
}

\author{
Rodolfo Maciel Fernandes ${ }^{1}$. Chafic Mustafé de Almeida ${ }^{3}$. Bruna Caldas Carvalho ${ }^{2}$. \\ João Alexandrino Alves Neto ${ }^{1}$ - Verônica Aparecida Costa Mota ${ }^{1}$. \\ Flávio Dutra de Resende ${ }^{1,3} \cdot$ Gustavo Rezende Siqueira ${ }^{1,3}$
}

Received: 13 April 2015 / Accepted: 24 September 2015 / Published online: 3 October 2015

(C) Springer Science+Business Media Dordrecht 2015

\begin{abstract}
The objective of this study was to evaluate the effect of increasing the supply of protein with different degradation rates on the performance and metabolism of growing Nellore cattle reared on Brachiaria brizantha cv. Marandu pasture during the transition period from the dry to rainy season. The experiment was installed on an area of $34 \mathrm{ha}$, divided into 12 paddocks with an average area of 2.85 ha. In the performance evaluation were utilized 72 recently weaned, non-castrated Nellore cattle with an initial body weight (BW) of $199 \mathrm{~kg}(\mathrm{SEM}=16)$. The following supplements were used: energy protein supplement containing $25 \%$ crude protein (CP) (C-25) and energy protein supplements containing $40 \%$ CP with one third highly degradable CP and two thirds poorly degradable CP (40-1/3NPN), one half highly degradable CP and one half poorly degradable CP (40-1/2NPN), and two thirds highly degradable $\mathrm{CP}$ and one third poorly degradable CP (40-2/3NPN). Higher protein degradation rates reduced supplement intake $(P<0.01)$. In the first period, animals consuming supplement $40-1 / 3 \mathrm{NPN}$ exhibited higher average daily gain (ADG) $(0.30 \mathrm{~kg} /$ day $)$, similar to that of animals receiving supplement $40-1 / 2$ NPN $(P=0.04)$. In the
\end{abstract}

Rodolfo Maciel Fernandes

rodolfo_fernandes@hotmail.com

1 Universidade Estadual Paulista "Júlio de Mesquita Filho", Faculdade de Ciências Agrárias e Veterinárias, Via de Acesso Professor Paulo Donato Castellane s/n, Jaboticabal, SP CEP: 14884-900, Brazil

2 Centro Universitário da Fundação Educacional de Barretos, Avenida Professor Roberto Frade Monte $n^{\circ}$ 389, Barretos, SP CEP: 14.783-226, Brazil

3 Agencia Paulista de Tecnologia dos agronegócios, Avenida Rui Barbosa s/n, CX 35, CEP: 14770-000, Colina, SP CEP: 14.783-226, Brazil second period, supplement 40-2/3NPN resulted in lower ADG $(0.19 \mathrm{~kg} /$ day less than the other supplements). There was no effect of supplement on animal performance in the third period $(P>0.10)$, when ADG was $0.56 \mathrm{~kg} / \mathrm{day}$. In conclusion, the response to supplementation is associated with interactions with characteristics of the forage canopy. Supplementation with a true protein source will be beneficial only during the early stage of the dry-rainy season transition period.

Keywords Protein levels · Supplementation · Protein degradation rates $\cdot$ Dry-rainy season transition

\section{Introduction}

Rapid qualitative and quantitative changes occur in the plant during the transition period from the dry to rainy season. First, in tropical condition, the quality and quantity of forage are low; however, immediately after the onset of the rainy season, a reduction in senescent material, an increase in leaves and crude protein $(\mathrm{CP})$, a reduction in neutral detergent fiber (NDF), and an increase in digestibility can be observed (Moretti et al. 2013). In this situation, the addition of protein elicits a positive animal response (Moretti et al. 2013), probably because of the high TDN/CP ratio of tropical forages during the transition period from the dry to rainy season, which increases the requirements of ruminal microorganisms for protein (Detmann et al. 2014).

Another important factor is the profile of the protein offered to the animal. Tropical forages contain high levels of non-protein nitrogen (NPN) (Moretti et al. 2013), a fact causing an imbalance in the ruminal release of protein and energy to microorganisms because of the rapid degradation rate of the NPN fraction (Ceconi et al. 2015). Different ratios of NPN and 
poorly degradable protein modify the synthesis of microbial protein, which can influence animal performance depending on the quality of the available forage.

Therefore, the objective of the present study was to evaluate the effect of increasing the supply of protein with different degradation rates on the performance and metabolism of growing Nellore cattle reared on Brachiaria brizantha cv. Marandu pasture during the transition period from the dry to rainy season.

\section{Material and methods}

All procedures have been conducted in accordance with the guidelines set out by the Brazilian College of Animal Experimentation in the Code of Practice for the Care and Use of Animals for Experimental Purposes and were reviewed and approved by the Animal Ethics Committee of the Sao Paulo State University (protocol no. 012683/13).

\section{Area, experimental period, animals, and pasture method}

The experiment was installed on an area of approximately 34 ha, divided into 12 paddocks with an average area of 2.85 ha. The evaluations were performed from August to November 2012 and comprised 14 days of adaptation and three periods of 28 days each, corresponding to 98 days of evaluation. Seventy-two recently weaned, non-castrated Nellore cattle with an initial body weight (BW) of $199 \mathrm{~kg}$ $(\mathrm{SEM}=16)$ and 7 to 9 months of age were used (tester animals). Continuous grazing with a variable stocking rate (put and take) was used as the grazing method according to Mott and Lucas (1952).

\section{Treatments}

Four experimental supplements $(3 \mathrm{~g} / \mathrm{kg} \mathrm{BW})$ were provided daily in the afternoon (13:00 h). The following supplements were used: energy protein supplement containing $25 \%$ crude protein $(\mathrm{CP})(\mathrm{C}-25)$ and energy protein supplements containing $40 \% \mathrm{CP}$ with one third highly degradable $\mathrm{CP}$ and two thirds poorly degradable CP (40-1/3NPN), one half highly degradable CP and one half poorly degradable CP (40-1/ 2NPN), and two thirds highly degradable $\mathrm{CP}$ and one third poorly degradable CP (40-2/3NPN) (Table 1$)$.

\section{Forage evaluation}

Estimates of forage mass were obtained at intervals of 28 days by the double sampling method (Sollenberger and Cherney 1995). For the evaluation of quantitative and structural components of the forage canopy, samples were collected at the average height of each paddock and divided into four fractions: green stem, green leaf, dead/senescent stem, and dead/senescent leaf.

Hand-plucked samples were used to estimate the nutritional value of the diets (De Vries 1995). These samples were dried at $55{ }^{\circ} \mathrm{C}$ in a forced draft oven for $72 \mathrm{~h}$ and then ground through a Wiley mill using a 1-mm mesh sieve and stored for further chemical analysis.

\section{Bromatological analysis}

Dry matter (934.01), mineral matter (942.05), CP (978.04), and ether extract (920.39) content was measured according to recommendations of the AOAC (1995). The content of NDF and acid detergent fiber (ADF) was determined by sequential analysis as described by Robertson and Van Soest (1981) using a TECNAL ${ }^{\circledR}$ TE-149 fiber analyzer (Piracicaba, SP, Brazil). Cellulose was solubilized with $72 \%$ sulfuric acid, and lignin content was obtained as the difference (Goering and Van Soest 1970). In vitro true digestibility of DM (IVTDDM) was determined as described by Van Soest and Robertson (1985). Forage protein was fractionated using the Cornell Net Carbohydrate and Protein System proposed by Sniffen et al. (1992) and described by Licitra et al. (1996).

\section{Ruminal parameters}

Four fistulated animals, selected among the same batch of tester animals, were divided into a $4 \times 4$ Latin square. Fluid samples were collected on day 20 of each period at time zero (before supplementation) and 6,12, and $18 \mathrm{~h}$ after offer of the supplement.

The $\mathrm{pH}$ was determined immediately after collection. A $50 \mathrm{~mL}$ aliquot which was acidified with $1 \mathrm{~mL}$ sulfuric acid (1:1) for analysis of ruminal ammonia nitrogen (RAN) by colorimetry according to Weatherburn (1967) and a $50 \mathrm{~mL}$ aliquot which was immediately frozen for analysis of VFA levels (acetate, propionate, butyrate, valerate, isobutyrate, isovalerate) by gas chromatography as described by Erwin et al. (1961).

\section{Weight determination}

Variations in weight were determined by weighing the animals at day 0 and again after 14 days (adaptation period). The subsequent weight recordings were performed at intervals of 28 days always after a $16-\mathrm{h}$ fast from solids and water.

\section{Statistical analysis}

A completely randomized block design was used for statistical analysis of performance parameters and forage characteristics, in which the area was the blocking factor. The paddock was the experimental unit adopted, with six tester animals per 
Table 1 Composition of the supplements (g/kg dry matter)

\begin{tabular}{lllll}
\hline Ingredient (g/kg dry matter) & \multicolumn{2}{l}{ Supplement } & & \\
\cline { 2 - 5 } & $\mathrm{C}-25$ & $40-2 / 3 \mathrm{NPN}$ & $40-1 / 2 \mathrm{NPN}$ & $40-1 / 3 \mathrm{NPN}$ \\
\hline Cottonseed meal & 388 & 226 & 459 & 655 \\
Corn & 522 & 568 & 359 & 186 \\
Urea & 30 & 96 & 71 & 49 \\
Premix & 110 & 110 & 110 & 110 \\
Composition & & & & 600 \\
TDN & 676 & 640 & 620 & 403 \\
Crude protein & 255 & 406 & 402 & 342 \\
NPN (g/kg NT) & 325 & 663 & 492 & 658 \\
Plant nitrogen (g/kg NT) & 675 & 337 & 508 &
\end{tabular}

Macronutrients and micronutrients ( $\mathrm{g} / \mathrm{kg}$ dry matter): calcium (minimum-maximum) 23,000 to 27,000; phosphorus (minimum) 6000; magnesium (minimum) 1000; sulfur (minimum) 3000; sodium (minimum) 13,000; copper (minimum) 0.040; manganese (minimum) 0.030; zinc (minimum) 0.148; iodine (minimum); 0.003; cobalt (minimum) 0.002; selenium (minimum) 0.001; fluoride (maximum) 0.100; monensin 0.080

$N P N$ non-protein nitrogen, $N T$ nitrogen total paddock and three repetitions per treatment. The data were submitted to analysis of variance as repeated measures over time in mixed models, in which REPEATED was the evaluation period. For fermentation parameters, a $4 \times 4$ Latin square design was adopted. These data were also submitted to analysis of variance in mixed models, in which REPEATED was the time of assessment. All data were analyzed using the MIXED procedure of the SAS 9.2 program (SAS Institute 2008), adopting a level of significance of $10 \%$.

\section{Results}

\section{Quantitative and qualitative characteristics of the forage canopy are influenced by the evaluation period}

No differences $(P=0.11)$ in the quantitative or qualitative variables of the forage canopy were observed between supplements fed to the animals (Table 2). However, the experimental period had an effect on these variables $(P<0.07)$.

Forage mass was reduced by $1047 \mathrm{~kg} / \mathrm{ha}$ at the end of the experimental period $(P=0.07)$ compared to the other periods. The proportion of green leaves decreased by $47 \mathrm{~g} / \mathrm{kg} \mathrm{DM}$ during the first period but increased again at the beginning of the third period. The highest proportion of green leaves was observed at the end of the experimental period (approximately $73 \%$ compared to the beginning of the second period).

A similar trend was observed for NDF and ADF, with an increase in proportions from the beginning of the first period to the second period, a reduction at the beginning of the third period, and another increase at the end of the experimental period. In contrast, the proportion of lignin was reduced by about $20 \%$ at the beginning of the third period and at the end of the experimental period when compared to the values observed at the beginning of the first and second periods. The ratio of crude protein/truly digestible organic matter (TDOM) was significantly lower $(40 \%)$ only at the beginning of the second period compared to the other periods.

There was a decrease in $\mathrm{CP}$ of about $41 \mathrm{~g} / \mathrm{kg}$ DM during the first period $(P<0.01)$, and the value observed at the beginning of the second period $(52 \mathrm{~g} / \mathrm{kg} \mathrm{DM})$ was the lowest of the experimental period. Analysis of forage nitrogen fractions showed the lowest proportion of fraction $\mathrm{A}$ at the end of the experimental period $(175 \mathrm{~g} / \mathrm{kg} \mathrm{N})$. This value was on average $31 \mathrm{~g} / \mathrm{kg} \mathrm{N}$ lower than those of the other period $(P<0.01)$. With respect to the indigestible nitrogen fraction (fraction $C$ ), the lowest proportion was observed at the beginning of the first period $(P<0.01)$. An increase of $33 \mathrm{~g} / \mathrm{kg} \mathrm{N}$ in this fraction was detected at the beginning of the second period, which was higher compared to the other evaluations $(P<0.01)$.

\section{Ruminal parameters: Supplementation does not alter RAN concentration but modifies butyrate and isovalerate concentrations}

There was no effect of supplementation or of the interaction $(P=0.24)$ between supplement and time on RAN, acetate, propionate, and isobutyrate concentration, or $\mathrm{pH}$ (Table 3 ). Animals consuming 40-2/3NPN and 40-1/2NPN exhibited a ruminal concentration of butyrate that was on average $11 \%$ higher than that observed for animals supplemented with C-25 and 40-1/3NPN. An increase in isovalerate concentration of $0.21 \mathrm{mM}$ was observed in animals receiving supplement 40-2/3NPN compared to animals supplemented with higher protein levels but a lower proportion of NPN (40-1/2NPN and 40-1/3NPN). 
Table 2 Quantitative and qualitative characteristics of Marandu forage grass (simulated pasture) during the transition period from the dry to rainy season

\begin{tabular}{|c|c|c|c|c|c|c|c|c|}
\hline \multirow[t]{2}{*}{ Variable } & \multicolumn{4}{|c|}{ Period of evaluation } & \multicolumn{3}{|c|}{$P$ value } & \multirow[t]{2}{*}{ SEM } \\
\hline & $23 / 08$ & $21 / 09$ & $19 / 10$ & $15 / 11$ & $\mathrm{~S}$ & $\mathrm{P}$ & $\mathrm{S} * \mathrm{P}$ & \\
\hline Height (cm) & $25 \mathrm{~b}$ & $21 \mathrm{c}$ & $21 \mathrm{c}$ & $28 \mathrm{a}$ & 0.11 & $<0.01$ & 0.98 & 2.9 \\
\hline Forage mass (kg/ha) & $7316 a$ & $6807 \mathrm{a}$ & $6907 \mathrm{a}$ & $5963 \mathrm{~b}$ & 0.29 & 0.07 & 0.99 & 481 \\
\hline Green leaf (g/kg DM) & $153 \mathrm{c}$ & $106 \mathrm{~d}$ & $195 \mathrm{~b}$ & $371 \mathrm{a}$ & 0.36 & $<0.01$ & 0.58 & 7.4 \\
\hline Greed stem (g/kg DM) & $174 \mathrm{a}$ & $131 \mathrm{~b}$ & $148 \mathrm{~b}$ & $138 \mathrm{~b}$ & 0.33 & $<0.01$ & 0.63 & 12.4 \\
\hline Dead leaf (g/kg DM) & $307 \mathrm{~b}$ & $333 \mathrm{a}$ & $278 \mathrm{c}$ & $249 \mathrm{~d}$ & 0.89 & $<0.01$ & 0.26 & 8.9 \\
\hline Dead stem (g/kg DM) & $366 \mathrm{~b}$ & $431 \mathrm{a}$ & $380 \mathrm{~b}$ & $252 \mathrm{c}$ & 0.6 & $<0.01$ & 0.85 & 9.8 \\
\hline \multicolumn{9}{|c|}{ bromatological composition } \\
\hline NDF (g/kg DM) & $610 \mathrm{~b}$ & $670 \mathrm{a}$ & $610 \mathrm{~b}$ & $670 \mathrm{a}$ & 0.92 & $<0.01$ & 0.78 & 0.8 \\
\hline $\mathrm{ADF}(\mathrm{g} / \mathrm{kg} \mathrm{DM})$ & $300 \mathrm{~b}$ & $340 \mathrm{a}$ & $290 \mathrm{c}$ & $340 \mathrm{a}$ & 0.94 & $<0.01$ & 0.34 & 0.5 \\
\hline Lignin (g/kg DM) & $70 \mathrm{a}$ & $69 \mathrm{a}$ & $60 \mathrm{~b}$ & $51 \mathrm{~b}$ & 0.7 & $<0.01$ & 0.53 & 2.0 \\
\hline TDOM (g/kg DM) & $600 \mathrm{~b}$ & $521 \mathrm{c}$ & $710 \mathrm{a}$ & $601 \mathrm{~b}$ & 0.89 & $<0.01$ & 0.98 & 17.4 \\
\hline g CP/kg TDOM & $159 \mathrm{a}$ & $96 \mathrm{~b}$ & $166 \mathrm{a}$ & $178 \mathrm{a}$ & 0.99 & $<0.01$ & 0.99 & 5.3 \\
\hline \multicolumn{9}{|l|}{ nitrogen fraction } \\
\hline $\mathrm{CP}(\mathrm{g} / \mathrm{kg} \mathrm{DM})$ & $93 \mathrm{~b}$ & $52 \mathrm{c}$ & $119 \mathrm{a}$ & $107 \mathrm{~b}$ & 0.99 & $<0.01$ & 0.99 & 4.5 \\
\hline $\mathrm{A}(\mathrm{g} / \mathrm{kg} \mathrm{N})$ & $221 \mathrm{a}$ & $207 \mathrm{a}$ & $191 \mathrm{a}, \mathrm{b}$ & $175 \mathrm{~b}$ & 0.84 & $<0.01$ & 0.82 & 9.9 \\
\hline $\mathrm{B} 1+\mathrm{B} 2(\mathrm{~g} / \mathrm{kg} \mathrm{N})$ & $407 \mathrm{c}$ & $479 \mathrm{a}, \mathrm{b}$ & $458 \mathrm{~b}$ & $484 \mathrm{a}$ & 0.97 & $<0.01$ & 0.84 & 16.6 \\
\hline B3 (g/kg N) & $262 \mathrm{a}$ & $190 \mathrm{c}$ & $236 \mathrm{~b}$ & $219 \mathrm{~b}$ & 0.79 & $<0.01$ & 0.41 & 9.9 \\
\hline $\mathrm{C}(\mathrm{g} / \mathrm{kg} \mathrm{N})$ & $103 \mathrm{c}$ & $136 \mathrm{a}$ & $112 \mathrm{~b}$ & $107 \mathrm{c}$ & 0.43 & $<0.01$ & 0.93 & 6.4 \\
\hline
\end{tabular}

Means in the same line followed by the same letter do not differ between periods by the $t$ test at a $10 \%$ level of significance

$S$ supplement, $P$ period, $S^{*} P$ interaction between supplement and period, $D M$ dry matter, $N D F$ neutral detergent fiber, $A D F$ acid detergent fiber, $p d N D F$ potentially digestible neutral detergent fiber, TDOM (\%) truly digestible organic matter, $C P$ crude protein

\section{Supplementation modifies supplement intake}

There was an interaction between collective supplement intake and experimental period $(P=0.08)$ (Fig. 1). In the first period, similar intake was observed for animals supplemented with $40 \%$ protein. However, animals receiving supplement C-
25 consumed $6 \%$ more feed than animals receiving supplement 40-2/3NPN $(P<0.01)$.

In the second period, animals receiving the supplements containing protein with lower degradation rates $(\mathrm{C}-25$ and $40-1 / 3 \mathrm{NPN}$ ) consumed $0.3 \mathrm{~g} / \mathrm{kg}$ BW more feed than animals receiving the supplements with more degradable
Table 3 Concentrations of volatile fatty acids $(\mathrm{mM})$ and $\mathrm{pH}$ according to supplement at different sampling times

\begin{tabular}{|c|c|c|c|c|c|c|c|}
\hline \multirow[t]{2}{*}{ Variable } & \multicolumn{4}{|c|}{ Supplement } & \multirow[t]{2}{*}{$P$ value $(\mathrm{S})$} & \multirow[t]{2}{*}{$P$ value (Int) } & \multirow[t]{2}{*}{ SEM } \\
\hline & $\mathrm{C}-25$ & $40-2 / 3 N P N$ & $40-1 / 2 \mathrm{NPN}$ & $40-1 / 3 N P N$ & & & \\
\hline RAN & 16.5 & 16.1 & 16.7 & 15.8 & 0.98 & 0.24 & 2.3 \\
\hline Acetate & 81.3 & 82.7 & 78.2 & 75.9 & 0.34 & 0.57 & 7.6 \\
\hline Propionate & 23.8 & 22.0 & 19.9 & 22.1 & 0.26 & 0.89 & 2.4 \\
\hline Butyrate & $8.8 \mathrm{~B}$ & $10.2 \mathrm{~A}$ & $9.7 \mathrm{~A}$ & $8.7 \mathrm{~B}$ & 0.03 & 0.90 & 1.4 \\
\hline Isobutyrate & 0.8 & 0.8 & 0.8 & 0.8 & 0.54 & 0.68 & 0.9 \\
\hline Isovalerate & $1.2 \mathrm{AB}$ & $1.3 \mathrm{~A}$ & $1.1 \mathrm{BC}$ & $1.1 \mathrm{C}$ & 0.01 & 0.84 & 0.2 \\
\hline $\mathrm{pH}$ & 6.6 & 6.6 & 6.7 & 6.6 & 0.96 & 0.75 & 0.2 \\
\hline
\end{tabular}

Means in the same line followed by the same letter do not differ from one another by the $t$ test at a $10 \%$ level of significance

$S$ supplement, Int interaction between supplement and time, $R A N$ ruminal ammonia nitrogen 
Fig. 1 Supplement intake by Nellore animals during the transition period from the dry to period followed by the same lowercase letter do not differ by the $t$ test at a $10 \%$ level of significance rainy season. Means of the same

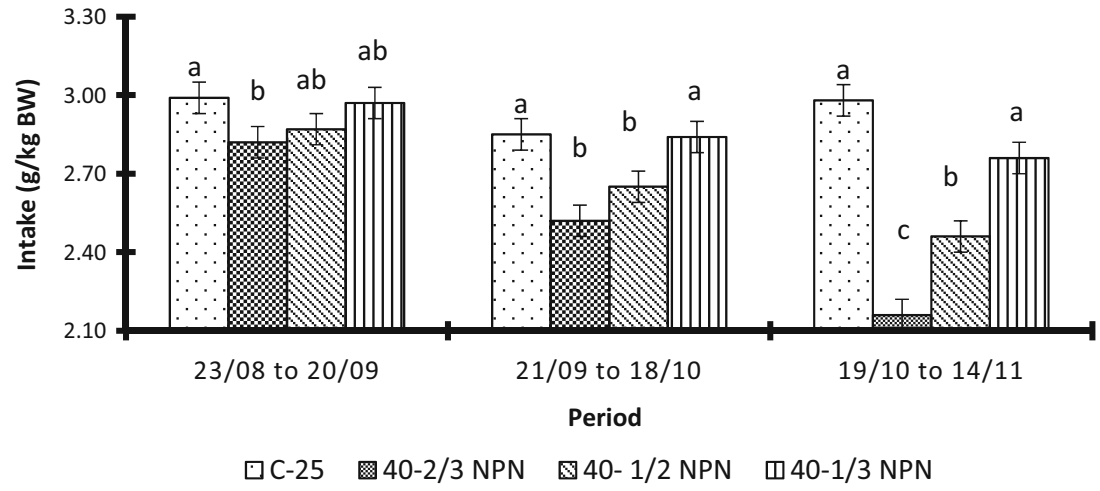

varied according to the supplement tested, supplementation did not alter $(P>0.10)$ the final BW of the animals (Table 4).

\section{Discussion}

Supplements containing different levels of protein with different degradation rates modify the average daily weight gain of animals

There was an effect of the interaction between supplement and experimental period on ADG $(P=0.04)$ (Fig. 2). In the first period, animals consuming the supplement with higher protein levels and lower protein degradation rates (40-1/ $2 \mathrm{NPN}$ and 40-1/3NPN) exhibited higher ADG compared to supplementation with lower protein levels (C-25). However, no improvement in performance was observed with increasing protein supply when a higher level of NPN was used (40-2/3NPN).

In the second period, the 40-2/3NPN supplement reduced ADG of the animals by approximately $0.16 \mathrm{~kg} /$ day compared to the average of the other supplements, which resulted in similar performance. Finally, no effect of the supplements on animal performance was observed in the third period. The ADG of these animals was $0.56 \mathrm{~kg} / \mathrm{day}$. Although ADG
Quantitative and qualitative characteristics of the forage canopy are influenced by the period of evaluation

The changes in the structure of the forage canopy observed over the experiment can be attributed in part to climatic variations, especially at the beginning of the second period. As observed in the present study, drastic changes in canopy characteristics normally occur during this season of the year (Moretti et al. 2013).

According to Poppi and McLennan (1995), maximum transfer of dietary protein to the animal's intestine is obtained when the ratio of $\mathrm{CP} / \mathrm{DOM}$ is $160 \mathrm{~g} \mathrm{CP} / \mathrm{kg} \mathrm{DOM}$. The $\mathrm{CP} /$ DOM ratio was below the recommended only at the beginning of the second period. The present results demonstrate that the animals do not respond to an increase of more than $25 \%$ in supplemental protein when the forage ratio is higher than $166 \mathrm{~g} \mathrm{CP} / \mathrm{kg}$ DOM.
Fig. 2 Average daily weight gain of growing Nellore animals during the transition period from the dry to rainy season according to supplement. Means of the same period followed by the same lowercase letter do not differ by the $t$ test at a $10 \%$ level of significance

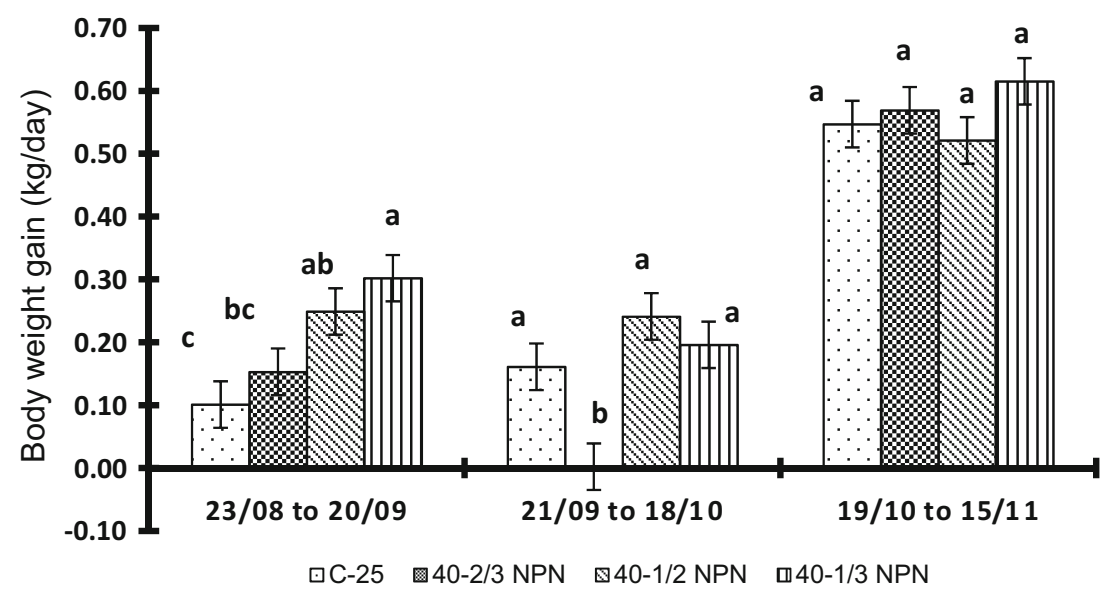


Table 4 Initial and final body weight of Nellore animals receiving supplements during the transition period from the dry to rainy season

\begin{tabular}{llllllll}
\hline Variable & \multicolumn{2}{l}{ Supplement } & & Mean & $P$ value & SEM \\
\cline { 2 - 5 } & C-25 & $40-2 / 3 \mathrm{NPN}$ & $40-1 / 2 \mathrm{NPN}$ & $40-1 / 3 \mathrm{NPN}$ & & & \\
\hline Initial weight $(\mathrm{kg})$ & 199 & 198 & 199 & 199 & 199 & 0.85 & 15 \\
Final weight $(\mathrm{kg})$ & 229 & 228 & 233 & 237 & 232 & 0.30 & 15 \\
\hline
\end{tabular}

\section{Ruminal parameters: Supplementation does not alter rumen ammonia nitrogen concentration but modifies butyrate and isovalerate concentrations}

It was believed that the administration of supplements with different protein degradation rates would cause changes in RAN concentration. However, the velocity of supplement intake in the trough (data not shown) probably altered the pattern of ammonia nitrogen release in the rumen. Animals supplemented with C-25 consumed the supplement more voraciously than animals supplemented with $40 \%$ protein. The greater the inclusion of NPN in the supplements containing $40 \% \mathrm{CP}$, the slower the disappearance rate of the supplement in the trough, releasing RAN equivalent to that of supplements with lower protein degradation rates.

The lack of change in the production of acetate, propionate, and isobutyrate may be due in part to the concentrations of RAN. Ruminal fiber-degrading microorganisms use RAN as a primary nitrogen source. Since no changes in RAN concentrations were observed for the supplements tested, perhaps there was no change in the ruminal conditions of microorganisms and, therefore, no effect was observed.

The higher production of butyrate and isovalerate in animals consuming the supplement with higher degradation rates indicates an increase in proteolysis and protein deamination of the feed, since branched-chain fatty acids are a product of protein catabolism (Barbosa et al. 2001). The ruminal $\mathrm{pH}$ was always between 6.5 and 6.8 , values considered to be adequate for the growth of fiber-degrading microorganisms (Dijkstra et al. 2012).

\section{Supplementation modifies supplement intake}

The supplements with the highest protein degradation rates (40-2/3NPN and 40-1/2NPN) contain high urea levels in DM (26 g/kg BW and $19 \mathrm{~g} / 100 \mathrm{~kg}$ BW, respectively). Urea is known to be a limiting factor of feed intake due to its low acceptability by animals (Moraes et al. 2012), explaining the reduction of supplement intake.

According to Melo et al. (2015), animals graze selectively and usually seek the consumption of green leaves. In the first period, since the forage grass available for grazing by the animals was of poor quality and the participation of green leaves was low, the reduction in supplement intake was not yet expressive. In contrast, the occurrence of the first rains and shoot emergence in the second period led the animals to start depressing supplement intake in search for newly emerged leaves, particularly in the case of supplement 40-2/3NPN. In the third period, forage quality had improved, with marked participation of green leaves compared to the other periods. The high participation of this component in high-quality forage explains the marked rejection of supplements containing high levels of urea in their composition.

\section{Supplements containing different levels of protein with different degradation rates modify the average daily weight gain of animals}

The interaction between supplement and evaluation period reflects the variation in canopy characteristics over the experiment. At the beginning of the first period, feed was available for consumption by the animals but was of low quality. As a consequence, the animals responded positively to supplementation. This response can be attributed to the increase in protein supply. Correlating up with greater availability of nitrogen for ruminal microorganisms balances the CP/TDOM ratio with positive effects on forage fiber degradation and passage rate (Detmann et al. 2014). However, improvement in performance is only observed when protein supply consists of protein with lower rates of ruminal degradation.

The worst performance of the animals was observed in the second period. This finding was probably due to the qualitative and quantitative conditions of the forage grass, which initially exhibited a high cell wall proportion and low digestibility. Feeds with these characteristics negatively influence the rate of digesta passage through the gastrointestinal tract, which compromises consumption due to the filling effect (Santana Júnior et al. 2012).

In view of the low supplement intake of animals fed the 402/3NPN supplement, the supplemental nutrient supply was low and was aggravated by the protein profile of the forage that contained high levels of NPN. Under these conditions, even when the forage starts the period with $96 \mathrm{~g} \mathrm{CP} / \mathrm{kg}$ DOM and reaches $166 \mathrm{~g} \mathrm{CP} / \mathrm{kg}$ DOM, the addition of supplemental NPN is not efficient even in providing low ADG of the animals.

In the third and last period, no difference in ADG of the animals was observed between supplements. However, we noted improved performance of the animals during this period as a result of the fact that the pasture exhibited characteristics 
of the rainy season. Since the increase in protein supply did not increase animal performance, it can be assumed that the use of supplements containing up to $25 \% \mathrm{CP}$ would be sufficient to adjust protein deficiencies of forage, irrespective of the protein source.

\section{Conclusion}

With respect to animal performance, the response to supplementation was associated with interactions with canopy characteristics. An increase in the protein concentration of the supplement will only have a potential effect during the early stage of the dry-rainy season transition when forage quality is low. This increase should be achieved with a true protein source.

Acknowledgments This study was funded by Fundação de Amparo a Pesquisa do Estado de São Paulo (FAPESP).

Conflict of interest The authors declare that they have no conflict of interest.

\section{References}

AOAC, 1995. Official Methods of Analysis of AOAC International, 16th ed. Association of Official Analytical Chemists, Arlington.

Barbosa, N.G.S., Lana, R.P., Jham, G.N., Borges, A.C., Mâncio, A.B., Pereira, J.C., Oliveira, J.S., 2001. Feed intake and ruminal fermentation of proteins as a function of energetic and proteic food supplementation of steers. Revista Brasileira de Zootecnia, 30, 1558-1565.

Ceconi, I., Ruiz-Moreno, M.J., DiLorenzo, N., DiCostanzo, A., Crawford, G.I., 2015. Effect of slow-release urea inclusion in diets containing modified corn distillers grains on total tract digestibility and ruminal fermentation in feedlot cattle. Journal of Animal Science, 93, 4058-4069.

Detmann, E., Valente, E.E.L., Batista, E.D., Huhtanen, P., 2014. An evaluation of the performance and efficiency of nitrogen utilization in cattle fed tropical grass pastures with supplementation. Livestock Science, 162, 141-153.

De Vries, M.F.W., 1995. Estimating forage intake and quality in grazing cattle: a reconsiderarion of the hand-plucking method. Journal of Range Management, 48, 370-375.

Dijkstra, J.; Ellis, J.L.; Kebreab, E., Strathe, A.B., López, S., France, J., Bannink, A., 2012. Ruminal $\mathrm{pH}$ regulation and nutritional consequences of low pH. Animal Feed Science and Technology, $172,22-44$.

Erwin, E.S.; Marco, G.J.; Emery, E.M., 1961. Volatile fatty acid analyses of blood and rumen fluid gas chromatography. Journal of Dairy Science, 44, 1768-1771.

Goering, H.K., Van Soest., P.J., 1970. Forage fiber analysis (Apparatus, reagents, procedures and some applications). Washington, DC: USDA.

Licitra, G., Hernandez, T.M., Van Soest, P.J., 1996. Standardization of procedures for nitrogen frations of ruminant feeds. Animal Feed Science and Technology, 57, 347-358.

Melo, J.C., Alexandrino, E., Neto, J.J.P., Silva, A.A.M., Neiva, J.N.M., Rezende, J.M., 2015. Preference of fodder marandu-grass (Urochloa brizantha cv. Marandu) managed under intermittent stocking and submitted to nitrogen levels in the legal Amazon. Semina: Ciências Agrárias, 36, 2713-2726.

Moraes, E.H.B.K., Paulino, M.F., Zervoudakis, J.T., Detmann, E., Valadares Filho, S.C., Moraes, K.K., 2012. Productive and economic aspects of crossbreed steers fed protein-energy supplements with urea. Revista Brasileira de Zootecnia, 41, 1278-1284.

Mott, G.O., Lucas, H.L., 1952. The desing, conduct, and interpretation of grazing trials on cultivated and improved pastures. In: INTERNATIONAL GRASSLAND CONGRESS, 6, Pennsylvania. Proceedings... Pennsylvania: State College Press, pp.1380-1385.

Moretti, M.H, Resende, F.D., Siqueira, G.R., Roth, A.P.T.P., Roth, M.T.P., Campos, W.C., Ferreira, L.H., 2013. Performance of Nellore young bulls on marandu grass pasture with protein supplementation. Revista Brasileira de Zootecnia, 42, 438-446.

Poppi, D.P., McLennan, S.R. 1995. Protein and energy utilization by ruminants at pasture. Journal of Animal Science, 73, 278-290.

Robertson, J.B., Van Soest, P.J., 1981.The detergent system of analysis and its application to human foods. In: JAMES, W.P. T.; THEANDER, O. The analysis of dietary fiber in food. New York: Marcel Dekker, 123-158.

SAS Institute. 2008. SAS/STAT 9.2 User's Guide. SAS Institute, Inc. Cary, NC, USA.

Santana Júnior, H.A., Silva, R.R., Carvalho, G.G.P., Silva, F.F., Mendes, F.B.L., Abreu Filho, G., Trindade Júnior, G., Cardoso, E.O., Barroso, D.S., Pereira, M.M., 2012. Correlation between digestibility and ingestive behavior of heifers supplemented at pasture. Revista Archivos de Zootecnia, 61, 549-558.

Sniffen, C.J., O’Connor, J.D., Van Soest, P.J., Fox, D.G., Russell, J.B., 1992. A net carbohydrate and protein system for evaluating cattle diets: II. Carbohydrate and protein availability. Journal of Animal Science, 70, 3562-3577.

Sollenberger, L.E.; Cherney, D.J.R., 1995. Evaluating forage production and quality. In: Barnes, R.F., Miller, D.A., Nelson, C.J. (Eds.) Forages: the science of grassland agriculture. Ames: University Press.2, 97-110.

Van Soest, P.J., Robertson, J.B., 1985. Analysis of forages and fibrous foods. Ithaca: Cornell University Press, 202p.

Weatherburn, N. W., 1967. Phenol-hypochlorite reaction for determination of ammonia. Analytical Chemistry, 39, 971-974. 